Vol. 6, n² | 2002

Varia

\title{
Handbooks and local jurisdiction in Ming China. According to the sections on judicial matters in the «Shih-cheng lu» by Lü K'un, a handbook for magistrates
}

Dominiek Delporte

\section{(2) OpenEdition}

\section{Journals}

Electronic version

URL: https://journals.openedition.org/chs/412

DOI: $10.4000 /$ chs. 412

ISSN: 1663-4837

\section{Publisher}

Librairie Droz

\section{Printed version}

Date of publication: 1 December 2002

Number of pages: $22-49$

ISBN: 2-600-00812-8

ISSN: $1422-0857$

\section{Electronic reference}

Dominiek Delporte, "Handbooks and local jurisdiction in Ming China. According to the sections on judicial matters in the "Shih-cheng lu» by Lü K'un, a handbook for magistrates", Crime, Histoire \& Sociétés / Crime, History \& Societies [Online], Vol. 6, n² | 2002, Online since 25 February 2009, connection on 23 March 2022. URL: http://journals.openedition.org/chs/412 ; DOI: https://doi.org/ $10.4000 /$ chs. 412

This text was automatically generated on 23 March 2022.

(c) Droz 


\title{
Handbooks and local jurisdiction in Ming China. According to the sections on judicial matters in the «Shih-cheng lu» by Lü K'un, a handbook for magistrates
}

\author{
Dominiek Delporte
}

1 In imperial China, judicial matters fell under the authority of administrators at all levels of the civil and military administration. For most of these officials, their judicial function was only one of the many functions they had to exercise; they also were responsible for matters such as tax collection, public works, ceremonial observances, or the supervision of granaries. Few of them had enjoyed specialized judicial training, but they were nevertheless expected to have enough knowledge of the law and of judicial procedures to be able to perform their judicial duties'2.

2 In order to improve the judicial knowledge and skills of these officials, and in order to help them to avoid malpractices, commentaries on the codes - originally only by government functionaries in their official capacity, but from the Yüan dynasty (1279-1368) on also by private individuals - and handbooks for magistrates were compiled. This form of literature was aimed at explaining the meaning of the statutes and at advising the officials on their application. Some of the handbooks are reprints of the code with interlinear commentary between the statutes and sub-statutes, others are case collections in which the decision in each case is motivated with stipulations from the code, precedents, or moral concepts. A third group of handbooks is formed by manuals that give practical advice for each procedure the civil officials were responsible for. Handbooks belonging to this last group also contain some excerpts from the code, and illustrate important steps in the procedures by means of specific cases.

In comparison with the administrative regulations and the official histories, the handbooks for magistrates give a much more realistic insight into judicial practice and into civil 
administration in general. The former shows us how the judicial system was ideally supposed to work, whereas the latter point out how it functioned in reality. Other interesting sources that enable us to see some of the problems and shortcomings of the judicial administration are memorials, directed to the throne by officials whose anger was frequently triggered by malpractice on different levels of the administrational hierarchy ${ }^{3}$.

\section{The most influential handbooks}

Some handbooks for magistrates written under the Southern Sung (1127-1279) and Ming (1368-1644) dynasties remained influential until the end of the Ch'ing dynasty (1644-1912). In 1211, the «T'ang-yin pi-shih» («Parallel cases from under the pear-tree») ${ }^{4}$, a collection of law cases serving as a manual for judicial officials, was published by Kuei Wan-jung. This work is a collection of reports on 144 cases, judged between 300 B.C. and A.D. 1100. It is more anecdotal than technical however, and it even contains legendary sections. ${ }^{5}$

5 A more realistic work, and also one of the most famous and influential handbooks in Chinese legal history, is a book on forensics written during the Southern Sung, entitled «Hsi yüan lu» («Essay on the washing away of wrongs») ${ }^{6}$, by Sung Tz'u (1186-1249), who served in several local administrative and judicial posts. He wrote the handbook using his own experience and material from earlier handbooks. The «Hsi yüan lu» was completed around 1247 .

6 The work of Sung Tz'u was imitated by others, in works bearing titles such as «P'ing yüan lu» («Essay on the redressing of wrongs», by Chao I-chai)and «Wu yüan lu» («Essay on the avoiding of grievances», compiled in the Yüan (1279-1368) by Wang Yü). Several similar works from the Ch'ing dynasty (1644-1912) are entitled «Hsi yüan chilu» («Collected writings on the washing away of wrongs»). In these works, new elements were added to the material given in Sung Tz'u's book ${ }^{7}$.

7 More comprehensive handbooks from the Yüan are the «Kuan-min chungyung» («Standard references for officials and civilians») and the «Shih-min yaolan» (Essential references for officials and civilians») ${ }^{8}$.

8 An important example of a Ming manual is the «Lin min pao-ching» («Precious mirror for governing the people»), by Su Mao-hsiang, published in 1632. It is a reprint of the code with commentary added between each article. Yüan and Ming texts on forensics (the «P'ing yüan lu» and the «Wu yüan lu») were appended to this work' .

9 Many handbooks originated in the author's personal experience as a civil administrator. Lü K'un (1536-1618, alternative name Lü Hsin-wu) ${ }^{10}$, the author of the «Shih-cheng lu» («Record of practical government»), passed the three degrees of examinations for civil office ${ }^{11}$ between 1561 and 1574, and then started an impressive career in the civil administration. During this career, he was renowned for his discipline and integrity ${ }^{12}$. After having held two positions as a local magistrate, between 1574 and 1578 , he became a secretary in the ministry of personnel ${ }^{13}$ in 1578 . Also in this function, he stressed the importance of law and order, and rose to the position of bureau director. In 1587, he started his provincial career, becoming an administration vice commissioner ${ }^{14}$ of the province of Shan-tung; in 1589, he was appointed as a surveillance commissioner ${ }^{15}$ for the province of Shan-hsi; in 1591 and 1592, he served as an administration commissioner ${ }^{16}$ for the province of Shen-hsi, and between 1592 and 
1594, he was the governor of Shan-hsi ${ }^{17}$. During the time he held these provincial posts, he issued collections of written advice to his subordinates and colleagues, as introductions to the civil and judicial local administration ${ }^{18}$. He issued five different documents comprised of prescriptions: «Ming-chih» (prescriptions for provincial officials), «Hsiang-chia yüeh» (prescriptions for local sub-official personnel), «Feng-hsien yüeh» (advice for provincial surveillance officials and censors ${ }^{19}$ ), «Yücheng» (prescriptions for officials in charge of prisons), and «Tu-fu yüeh» (advice for governors and governors-general). In 1598, these were printed together under the title «Lü-kung shih-cheng lu» («Record of practical government by Lord Lü»). His handbook was later abridged and adapted, and remained an important manual for provincial magistrates during the Ch'ing dynasty (1644-1912), under the title «Shih-cheng lu» («Record of practical government») $)^{20}$.

New handbooks also appeared during the Ch'ing. The most influential ones were the «Mu-ling shu» («Compendium on magisterial service», compiled in 1848 by Hsü Tung), the «Fu-hui ch'üan-shu» ("Complete book on well-being and benevolence», edited in 1694 by Huang Liu-hung) and the «Hsüeh-chih $i$-shuo» («Views on learning governance», published by Wang Hui-tsu (1731-1807) in 1793). The «Mu-ling shu» was extremely important, since it was the most comprehensive handbook, bringing together selections from influential authors throughout the Ch'ing dynasty ${ }^{21}$.

\section{The importance of Lü K'un's manual}

11 Handbooks like the «Hsi yüan lu», the «Shih-cheng lu» and the Ch'ing handbooks give us an abundance of practical instructions for judicial procedures. Whereas the «Hsi yüan lu» and its descendants concentrate mainly on investigations in murder cases, the «Shih-cheng lu» lists dozens of prescriptions for each procedure- inquests, investigations, arrests, hearings, and sending of reports - and illustrates some of them with examples from actual cases. These prescriptions provide us with important information about the practical functioning of the judicial system. Instructions to the magistrates on how to avoid malpractice and abuse inevitably also point out the shortcomings of the Chinese judicial system. The authors of the handbooks had, without any doubt, personally experienced such malpractice during their career in the civil administration.

During the Ming dynasty (1368-1644), the handbooks were essential sources of information on law and judicial procedures, not only because many officials were insufficiently trained, but also because the Ming code, after its final revision in $1389^{22}$, was supposed to remain unchanged throughout the entire dynasty ${ }^{23}$, so that, as time moved on, the code was no longer in accordance with social reality, and officials started to experience problems in applying the existing code ${ }^{24}$. These problems were especially critical in cases of civil nature, the so-called «minor matters of households, marriages, and land» («hu, hun, t'ien-t'u hsi-shih»). These matters were not always sufficiently recognized by the code, since they were supposed to be dealt with on the informal level. Handbooks could give the officials practical instructions on how to deal with matters for which the code could not offer a solution.

13 Lü K'un's manual is less moralising and more pragmatic than many other handbooks. He was motivated less by purely moral principles than by the awareness that welleducated subordinates would ensure a correct and efficient functioning of the local 
government agencies. Moral considerations are comparatively rare in his «Shih-cheng $l u\rangle^{25}$. Occasionally, we find remarks such as:

"If the superior classes do not reform them by means of instruction, the lower classes will not have any knowledge» ${ }^{26}$.

"The duties of the local authorities lie in redressing wrongs and in making injustices right» ${ }^{27}$.

These statements clearly reflect a Confucianist view of government and justice: officials have to set an example for the population.

\section{The sections on judicial matters in the «Shih-cheng Lu», chapter «Feng-hsien Yüeh»}

17 All quotations below - translated from the original classical Chinese text - are drawn from the chapter entitled «Feng-hsien yüeh», the exhortations for surveillance officials (the censors in the capital, the regional inspectors, and the provincial administration commissions), since they were the ones charged with revealing malpractice amongst the other officials, and with taking corrective and punitive measures to redress or prevent it. They had to conduct regular and irregular evaluations of local magistrates. The prescriptions and criticisms that Lü K'un directs at them give us, more than any other chapter in his work, an idea of the shortcomings of the judicial system, especially on the local level, and of the difficulties in applying the law at the end of the sixteenth century.

For each specific procedure that local officials had to deal with, the sections on «judicial matters» («t'i-hsing shih-yi») in the chapter «Feng-hsien yüeh» give specific guidelines on how to carry out that procedure and on how to avoid or solve problems that might arise when carrying it out. For conducting investigations in murder cases, the guidelines consist of 12 'articles' in total; for investigating theft and robbery, Lü K'un's advice is 11 articles long; the prescriptions for dealing with sexual offences consist of 4 articles; there are 10 articles on arrests and imprisonment; 12 on hearing trials; and 4 on the use of instruments of torture and punishment. This is followed by a series of models of official forms, used for formulating complaints and accusations.

19 The instructions were all directed towards officials responsible for supervising the functioning of local administrative levels. They stress primarily the initial stages in the trying of a case, and not, or to a much lesser extent, such matters as higher appeals or the granting of amnesties. The latter belonged to the activities of higher judicial organs on or above the provincial level.

\section{a. Instructions for correct investigations in cases of murder or robbery}

Lü K'un begins the chapter «Feng-hsien yüeh» with instructions for the conducting of examinations in murder cases and in cases of theft and robbery. Although his instructions for the conducting of forensic examinations are less elaborate than those given by Sung Tz'u in his «Hsi yüan lu», it is obvious that Lü K'un used material from the «Hsi yüan lu», or from later works modelled on the work of Sung Tz'u, to compose his guidelines for holding inquests. A few times, he even refers to the «Hsi yüan lu». 
21 Lü K'un encourages officials to deal with all important aspects of the investigation themselves, without delay - because delay makes it possible for evidence or witnesses to disappear, and enables the parties involved to produce false evidence or to bribe witnesses - and without relying on sub-official functionaries ${ }^{28}$ or lower officials for important procedures-because their low salary ${ }^{29}$ makes them eager to accept bribes, and because they often neglect their duty. The problem was that the clerks and runners, who were recruited locally by the heads of prefecture, sub-prefecture or district through a network of power and influence, escaped control by the central government, and that they wielded a lot of real power in the local territorial units. Because they did most of the practical work, they were much more familiar with legal matters and provisions than the officials they worked for. In addition, their pay was fixed at a low rate, and they had no choice but to collect supplementary payments in the form of fees, often paid by people involved in a lawsuit. Some also collected money from the local residents by cheating when collecting land tax, or by extorting money from suspects or their families when making investigation reports; others demanded fees for delivering messages or for handing in tax payments to the local government ${ }^{30}$. Not surprisingly, this made them unpopular with both the local population and their superiors. Traditionally, the way they have been depicted in Chinese literature - and in manuals for officials - is far from flattering. Lü K'un is very sceptical towards "the sub-official functionaries who have received assignments [...] Do they have their minds set on fairness? Or on selfish motives?» ${ }^{31}$.

Lü K'un criticizes the habit officials had of passing on important stages in the investigation to their staff (clerks, runners, police officers), because they had no time to go through these procedures themselves, or because they wanted to avoid the most unpleasant procedures - such as examining corpses.

"When an inquest is held, the officials who have received the assignment [for the inquest] are disgusted by the uncleanness of the murder scene, [so that] none of them approaches the dead body $»^{32}$.

24 The author is strict and formal when it comes to the responsibility of the official to conduct an investigation, and his duty to do this within the prescribed period. He states as a general rule, leaving room for only a few exceptions, that «in murder cases, on the day when a notice of the facts and a court order for investigation reach them, [the officials] immediately [have to] leave their office duties behind, in order to go and conduct an examination. If they can come to a conclusion on the spot, then they write out a notice and a report on that same day. If the official who is charged with [the investigation] is really ill, or if it is absolutely necessary that he attends to [other] matters, then, when the despatch reaches him, he has to decline [the request to investigate] immediately, in order to make it possible to send somebody else. A section in the 'Hsi yüan lu' determines that not more than two hours should elapse before one leaves to go and investigate» ${ }^{33}$.

The second group of cases addressed by Lü K'un are robberies and thefts. He reminds his fellow officials and subordinates of the frequency of fraudulentevidence in these cases. The officials should spare no effort to recover the stolen goods, and to determine whether goods were really stolen or not. Lü K'un does not hesitate to mention some spectacular stories about how he or his fellow officials observed different forms of fraud.

"Recently, there was [a case in which the officials] suspected an innocent person of being a robber. They searched his house, and found a yellow skirt. They pointed it out as a stolen object. The [person who pretended to be] the original owner of the stolen good claimed to recognize it [on the basis of the fact that it was] wool from T'ai-yüan ${ }^{34}$. The assistant-prefect brought a 
number of skirts from the pawn-shop. Each had a different waist size. They laid them out in court, and the [person who claimed to be] the original owner of the stolen property did not know which one to recognize [as being his]. He chose the wrong one, and [gave] inconsistent [answers]. When the innocent person [who had been accused of stealing the skirt] arrived, he could say, without hesitation: 'This is my skirt'. [The one who claimed to be] the owner of the stolen good had nothing to say. The innocent person was then released. From now on, when the authorities investigate stolen goods, they cannot act without consideration» ${ }^{35}$.

Lü K'un estimates that false claims, such as the accusation in the story translated above, add up to half of the accusations in cases of robbery and theft. Furthermore the clerks and runners were sometimes involved in these plots. He proves this by means of another savory story:

"There are people who have no choice but to 'recognise' the stolen goods, since the runners [who cannot find the real thieves] force them to. Sir L $\ddot{u ̈}^{36}$ of Ts'ang-nan ${ }^{37}$ told [me]: 'When I made a tour of inspection in $\mathrm{Hai}^{-y u^{38}}$, there was [the case of] a widow who was robbed. Ten people were arrested on a charge of robbery. The goods [in the possession of these suspects] that were [thought to be] stolen were searched through [by the runners]. Amongst these goods, there was a pair of women's shoes. The runners passed by the widow's house, and told her what the shoes [she had to report to the authorities as stolen] looked like. Subsequently, the district officials examined the 'stolen goods'. The widow then [pretended she] recognized each single one of them. When asked about the shoes, she said: 'They are my daughter's shoes'. When [the district officials] asked her what size they were, she told them what they looked like. When [her description was] compared with the model [of the shoes] they had found in the house [of one of the ten suspects], there was not the slightest difference. The ten had no words to explain this. When their punishment was only a few days away, the real thieves were all arrested, and the real stolen goods were all discovered. As for the ten [innocent] people, it could be clarified that the goods, previously thought to be stolen, were their property ${ }^{39}$.

By citing these anecdotes, Lü K'un tries to convince officials not to accept claims uncritically, since they were liable for punishment if they made a wrong judgment ${ }^{40}$. The effect of this situation was, not surprisingly, that officials were often reluctant to accept claims. Furthermore, investigating whether the plaint was true or not put such a heavy burden on officials that they immediately refused to accept certain plaints. Additionally, the officials in whose jurisdiction there was the lowest number of offences were regarded as the best officials; hence, many officials tried to disguise the fact that criminal acts occurred in their jurisdiction. If the facts could not be hidden, they had to solve the case by the end of the imposed deadline and, as a consequence, produce an offender. This often meant that officials or sub-official functionaries who could not find the culprit, intimidated innocent people and forced them to plead guilty.

\section{b. Instructions for dealing with sexual offences}

30 Cases involving sexual offences could be extremely troublesome for the magistrates who had to judge them, because «in cases of illicit sexual behaviour, there is normally no testimony. False accusations are easily made, and it is difficult to clarify matters. [...] From now on, each time an accusation is entered in a case of illicit sexual intercourse, even if the woman in question confesses, do not allow the plaint to be filed. How can you know for sure that it is not so that her husband is forcing [her] to implicate somebody falsely, and how can you know that it is not so that the woman in question is scheming for certain things [by accusing a man of having illicit 
sexual intercourse with her]? [...] From now on, each time a woman commits suicide because her consensual adultery has come to light and she feels ashamed about it, or when she commits suicide because she has been beaten by her parents or her husband, and if the man who has pushed her to commit adultery also has no accusation of coercion brought against him [by the relatives of the woman who committed suicide], it is hard to have the man who was involved in the illicit sexual activities punished because he compelled her, through their adultery, to die» ${ }^{41}$.

It is obvious that in cases of rape and adultery as well, not all charges could be accepted ${ }^{42}$. Because the penalty for illicit sex with consent (beatings with a heavy bamboo staff) differed dramatically from the punishment for rape (death by strangulation), the responsibility of the officials who investigated and sentenced in these matters was extremely heavy, so that magistrates tended to shun this responsibility ${ }^{43}$.

32 Cases involving sexual offences were even harder to judge when they involved people who did not belong to the «morally educated» classes. The difference between the common people and the higher classes is, according to Lü K'un, that «men and women from poor families easily have promiscuous relations. The moral integrity of these uneducated people is very low. [...] Therefore, the common people and poor masses cannot be blamed without giving the matter consideration, by [judging them according to] the principles used for [judging] worthy men. Each time facts of illicit sex by these people have to be dealt with, [officials] should not adhere strictly to the letter of the law when there is the slightest sense of defiance of the law [by these people]» $\gg^{44}$.

officials are thus encouraged to use two standards in judging cases of adultery. The law needs to be applied strictly when the matter involves people from higher social classes, but when similar events occur among marginalized people, where women often have no choice other than to submit to coercion by men from their environment, the accusations should not be accepted that easily. Whereas the law makes no distinction between this form of coercive sexual intercourse, imposed by social pressure amongst the lowest classes of society, and pure adultery, Lü K'un is fully aware of the way social distinctions produce a great impact on sexual awareness and behaviour ${ }^{45}$.

\section{c. Instructions for arresting and imprisoning suspects}

The golden rule for arresting suspects is the same as for investigating stolen goods or corpses: do not rely on sub-official functionaries, do it in person.

"When offenders have to be arrested, [the officials] delegate runners [to go and arrest the suspect]. The common practices of those hired sub-official functionaries really are the greatest misfortune for the population. Recently, officials who want to break with malpractice and who care for the people, often proceed to the arresting of the offender themselves» ${ }^{46}$.

6 These «common practices of the sub-official functionaries» refer to bribery and to the arresting of innocent people in order to make them confess, abuses that could be avoided only by keeping important procedures out of the hands of clerks and runners.

Arrests were sometimes followed by a long period of imprisonment. The code of the Ming contains regulations that are meant to ensure a humane treatment of prisoners. Imprisonment was not a formally recognised sentence in itself; it was a measure taken to detain people who were awaiting trial (sometimes including the plaintiff and witnesses) or punishment. Nevertheless, many suspects spent many years in jail 
awaiting their trial or retrial, or their punishment. Contemporary descriptions ${ }^{47}$ show that conditions in Ming prisons were extremely harsh. Jailers, who also belonged to the group of sub-official functionaries, frequently extorted money from prisoners and maltreated prisoners who refused to pay ${ }^{48}$. Lü K'un favours a correct treatment of prisoners, and he wishes to put an end to the prevailing practices which meant that many did not survive imprisonment. He even wants to avoid the imprisonment of people who have committed minor crimes, and who have relatives who depend on them. He disapproves of «the conventional pattern of arresting offenders and sending them to jail. [The local officials] do not know that, when a man sits in prison, his whole family suffers. In some cases, they have elderly relatives and a household with no wife [to take care of those elderly people], sometimes they have a young wife and no sons or nephews [to protect her], in some cases the family is poor, and the way [to the prison] is long, so they cannot supply [the prisoner with food]. Sometimes there are sick people in the family, or [the prisoner] himself is ill, or, in the winter cold, he has no padded clothes. In some cases, [the prisoners] are destitute and hungry, and there is no money to put the prison in order. Even if a person is sentenced to death, it is still necessary to take [his situation] to heart; furthermore, how could it be appropriate to imprison them carelessly when they have committed minor deeds?» ${ }^{49}$.

If criminals must be imprisoned, Lü K'un holds the officials responsible for a humane treatment of these offenders. Since it was impossible for the local authorities to ensure a favourable treatment (especially free food) for all prisoners, the financially weakest ones had to receive special consideration. The main problem was that «the financial means of the authorities are truly not abundant. If the food for the prisoners would have to be totally provided for [by the authorities], how could all people [in prison] equally receive these benefits, and this for years on end? Now, I propose to make a distinction between three classes: except for the cases where [the authorities] are not allowed to give them [food] when they have committed most heinous crimes ${ }^{50}$, and except for the cases where [the authorities] are not allowed to give them [food] if their family is not very poor, and they have somebody to provide them [with food], [the authorities] give [the prisoners] a full ration when they have committed less severe deeds, and their family is extremely poor or they have no family to provide them [with food], and [the authorities] give them half their ration if they have committed less serious crimes, and their family is relatively poor, and does not have enough for daily expenditures» ${ }^{51}$.

This section clearly reflects the author's extremely realistic, practical and systematic approach to such matters.It is obvious that the local government agencies did not have unlimited financial means. The government budget that local magistrates received to finance the administrative expenses of their local offices was far from adequate; they had to impose different kinds of customary fees in their jurisdiction. Furthermore these fees were not always sufficient, since the population did not have the financial reserves to pay high fees on top of the regular taxes. A local magistrate always had to find a way to raise enough money to meet the expenses of his administration, without extracting too much money from the people ${ }^{52}$.

\section{d. Instructions for conducting trials}

40 Here, the author repeatedly reminds the officials who conduct trials that they have to respect the time limits for settling a case. Officials who do not respect the time limits are to be punished ${ }^{53}$. Lü K'un does not seem willing to allow any exceptions on this point: 

or sentencing somebody for the wrong crime, would result in a penalty for the magistrate himself), this litigation abuse, which burdened the local administrational units with endless useless work, was one of the main reasons why many plaints should not be accepted. There are also moral reasons not to accept these plaints, because "among the things that cause suffering for the people, none is worse than implicating others in a crime and being fond of litigation. Unscrupulous people often implicate 20 or 30 people in one legal plaint, [thereby] taking personal vengeance and benefiting themselves. In not even two or three out of ten of these cases, [these abusers] have crucial evidence of the offence. How should one believe and trust these cunning rogues? Each time they receive a plaint, the officials in charge have to comment on it immediately in a public court session ${ }^{62}$. If [the plaint] is irrelevant, then they must reject it» ${ }^{63}$.

This brings us again to the conclusion that magistrates should not accept plaints indiscriminatingly, especially not those about minor matters, in order to prevent the caseload of local administrational units from becoming overwhelming. If the number of 
penal matters in a local magistrate's jurisdiction was too high, he risked being found incompetent in his superiors' evaluations, since, according to the traditional Confucianist view on government and law, the task of a good government functionary was, in the first place, to prevent injustice from happening, rather than restoring what had gone wrong. Every three years, an official was evaluated by his immediate superiors. Their report was then handed over to the provincial authorities, who sent it to the central government. As a result of the evaluations, officials could be demoted, dismissed, promoted, or asked to retire. Besides these regular evaluations, the authorities also subjected magistrates to irregular evaluations ${ }^{64}$.

\section{e. Instructions for using «instruments of torture» ${ }^{5}$}

In this section, Lü instructs the officials on how and when to use the six authorised «instruments of torture» (the light bamboo staff, the heavy bamboo staff, the heavy stick, the wooden collarpiece, the handcuffs, and the fetters) ${ }^{66}$. The collarpiece and the fetters were used as additional punishments, whereas "the light and heavy bamboo and the heavy stick can only be used in cases involving serious offences, when [the offender] does not confess ${ }^{67}$.

Although Lü K'un favours a humane treatment of suspects and prisoners, he nevertheless allows the use of some «extra-legal» torture instruments, but only within certain limits. Here, two of Lü K'un's most important ideals seem to be in conflict: his concern for a humane treatment of suspects and convicts on one hand, and his fanatical belief in an efficient legal system, which included speeding up the judicial procedures, and especially the obtaining of confessions, on the other. In an attempt to find a compromise between these two principles, he limits the use of illegal torture as follows:

«Recently, among the officials who try cases, there are some who do not have refined feelings, and who do not have a patient character. For cases of theft, without making any distinction between robbery and burglary, and for murder cases, without making any distinction between true and false [accusations], as soon as [the accused] enters their office, [these officials] only rely on squeezing instruments. I cannot give a full description of these atrocities. From now on, if the evidence proves [the guilt of the accused], and the facts are indeed revealed, [but the offender] is not willing to confess, torture instruments like these can be used, [but] the squeezing cannot be done more than once. Pressing the fingers can only be done on two fingers, and the squeezing cannot last longer than two hours. Hoops [that are tightened around] the head cannot be used at allı ${ }^{68}$.

Illegal torture ${ }^{69}$ was common practice, since a confession was deemed to be the only way to settle a case satisfactorily. Although officials could be punished if they tortured somebody (the suspects, but also the witnesses) illegally, the frequent complaints about these practices prove that the pressure of having to find a culprit who confessed weighed heavier for the magistrates than their fear of being punished for maltreatment of suspects.

\section{f. Models of the forms for reporting crimes}

51 To report criminal facts to the authorities, a form needed to be filled out. The author gives in his handbook models of 27 different forms. Where blanks must be filled in, Lü offers the possibility of multiple choice, or he explains what kind of information needs 
to be given there. The uniformity of these forms would rule out misunderstandings, and serve his ideal of a smoothly working civil and judicial bureaucracy. If somebody wanted to enter an accusation, but did not use the required formulation, the plaint could not be accepted. In his handbook, Lü K'un explains the necessity of these standard forms. He determines that «what is now fixed as a model needs to be observed uniformly by all bureaus. If [a plaint] is not [composed] according to the fixed pattern,[but it is nevertheless accepted,] then it is easy to know which officials accept too much. Each time any of the prefectures, sub-prefectures or districts ${ }^{70}$ receives a legal plaint, the office [of that locality] is responsible for ordering its clerks to compose the documents. If, afterwards, [the form] is not filled in according to the model, then the clerks are liable for a serious punishment, and the accusation cannot be accepted» ${ }^{71}$.

Besides using the right form, the party that wanted to enter an accusation had to observe a number of other standard regulations:

«People are not allowed to bring a case before the officials in more than one place. They are also not allowed to add even one detail falsely [to the facts]. If [these regulations] are disregarded, it is examined and re-investigated. [Even] if [the plaintiff] has a long way to go [to reach the office where he can enter an accusation], it can [still] not be more than five days before he brings his plaint» $\rangle^{72}$.

4 Below, we have translated two of the models presented by Lü K'un. We have chosen forms that are used for matters of civil nature: a form for reporting financial debts, and a form for reporting disputes over so-called «household divisions».

«Model of a form for reporting financial debts:

'In district $(\mathrm{x})$, belonging to sub-prefecture $(\mathrm{x})$ in prefecture $(\mathrm{x})$, person $(\mathrm{x})$ has incurred debts. Because person $(\mathrm{x})$ was short of capital, somebody lent ( $\mathrm{x}$ ounces of silver or $\mathrm{x}$ piculs of grain) to person $(\mathrm{x})$ on the $(\mathrm{x})$ th day of the $(\mathrm{x})$ th month of the year $(\mathrm{x})$, and he added an interest of three percent a month ${ }^{73}$. He designated somebody to be the mediator, and [he made] a receipt for the borrowed money. Now, person (x)has, during several years, up to this day, not returned the least bit of the interest, or he has only returned (a certain amount) of the interest, and he still owes (a certain amount).Repeatedly, he has asked for a delay of payment, [but] no agreement was reached, [so now] it is reported to the authorities ${ }^{14}$.

Disputes over debts were usually resolved through a middleman, so that lawsuits over unpaid debts were not very numerous. The lender could turn to this mediator for help if the borrower did not repay; if this mediator also acted as a guarantor, he was supposed to pay in the case of non-payment by the borrower. For large amounts, the lender usually required pledged security ${ }^{75}$.

«Model of a form for reporting [arguments over] property:

'Person ( $\mathrm{x}$ ) from district (x), belonging to sub-prefecture ( $\mathrm{x}$ ) in prefecture $(\mathrm{x})$, is involved in a dispute concerning property. For a certain reason ${ }^{76}$, a certain (ancestor $\mathrm{x}$ ) left [to his sons or grandsons], (a number of houses, or $\mathrm{x}$ acres of land, or a capital consisting of $\mathrm{x}$ ounces of silver, or a number of women's ornaments or garments). Person (x)had to share it equally with certain (uncles or elder brothers), according to the family relationships. Now, person (x), taking advantage of the fact that he is a senior [relative], completely intimidates [the other relatives] and takes it all, and does not share it. Referring to the will, or to the testimony of a certain (relative or neighbour), it is reported' $\aleph^{77}$.

50 The procedure for this kind of household division (with an equal partition - usually between brothers - of land, houses, or furniture) was complex and easily led to 
conflicts. These divisions of family property involved mediators, who witnessed the division in order to avoid possible disputes in the future, so that lawsuits over household division were comparatively rare ${ }^{78}$.

61 Some of the forms (such as these for reporting unpaid debts or property disputes, and forms for reporting marital disputes) clearly dealt with matters of civil nature (the above-mentioned «minor cases of households, marriages and land»). The law expected magistrates to deal with penal matters, whereas civil matters (unless they involved criminal acts) had to be dealt with by informal justice, with middlemen (in conflicts over contractual matters) or community leaders acting as mediators trying to find a compromise. In most cases, the parties involved in a conflict turned to the official judicial organs only if no agreement could be reached through this informal justice system. If somebody did take his civil case to the local magistrates to reach a settlement, he had to convince the - often reluctant - magistrate to accept his plaint or petition. The primary condition for this was to use the standardized form to present the plaint.

\section{Conclusion}

62 Why, could one ask, does Lü K'un still warn officials against the corrupt behaviour of clerks and runners, against fraud by culprits and victims, and against their own shortsightedness, 350 years after Sung Tz'u had done the same, and even longer after Kuei Wan-jung had published his case book? Should the task of civil administrators not have become easier, since their number had increased ${ }^{79}$ ? Why did Lü K'un feel the need to write this new manual for magistrates?

63 It is impossible to state that the previous handbooks had become obsolete; many later versions of the handbooks from earlier dynasties were published during the Ming and Ch'ing dynasties ${ }^{80}$. Those later versions incorporated new elements, so that they kept in tune with recent developments.

64 To understand why Lü K'un compiled this new work, we need to be aware of the fact that he was an idealist, who was convinced that he had to do all that was in his power to promote social harmony and justice. When assuming his provincial posts, he wanted optimal co-operation from his subordinates, and he required that they be totally familiar with judicial procedures, in order to serve the public interest. Therefore, he wrote out these instructions. He carried his fanatical belief in order and perfection so far that he even started criticizing the emperor for his shortcomings, in his famous memorial of 1597. As a result, Lü was accused of dereliction of duty and dismissed ${ }^{81}$.

Another important factor is the fact that, although the number of officials had risen, their expertise and experience in many fields, including the legal field, often proved insufficient. Officials easily shifted from one function to another during their career, without having the chance to specialize in any one field. Furthermore, in most cases, the civil-service examinations did not test the candidates' legal and judicial knowledge ${ }^{82}$. The magistrates had to rely on the specialized knowledge of sub-official functionaries, such as clerks and technical aids, whose total number probably exceeded 100,000 during the Ming. Lü K'un felt the need to give the officials under his authority specific advice in order to improve their expertise, including in «minor cases of 
households, marriages and land», which were still too often overlooked by the central government and for which the stipulations in the official code proved insufficient.

Besides the lack of expertise, there were other important problems that threatened the smooth functioning of local government agencies, such as the heavy responsibilities of local magistrates in penal matters, the numerous abuses, and the overwork and financial limitations of the local administrative units. The heavy responsibilities consisted of the magistrate's liability for punishment if he made a wrong judgment, and of the fact that he had to keep the number of legal cases in his jurisdiction low enough to receive a favourable evaluation from his superiors; at the same time, he had to conclude the cases he dealt with in a satisfactory manner by finding an offender who would confess. This had to happen within the prescribed time limit, otherwise it could lead to his punishment and impeachment. Abuses, by their own staff (corruption, extortion, abuse of power) or by outsiders (drawing up and entering of false accusations), put a heavy burden on the local magistrates. Even the heavy penalties they risked did not deter abusers. Furthermore, as their caseload increased, local officials saw a great deal of their time consumed by often useless investigations - and they could not afford to waste any time, since there were always deadlines to be taken into account. In addition, some local government bureaus did not have the financial means to guarantee correct functioning and fair treatment of victims and suspects.

A major source of conflicts of interests, which formed the basis of many problems in local units of judicial administration, were the different motivations of officials and sub-official functionaries. The former wanted to keep the number of cases in their jurisdiction as low as possible, out of fear of a negative evaluation and because they simply did not have the time to deal with a great number of cases, whereas the latter wished to help anybody, reliable or not, to enter accusations, since their income directly depended on the number of cases for which they helped to draw up documents or for which one of the parties bribed them.

An important question that remains unanswered is: do Lü K'un's guidelines make the task of officials easier in the end and do they help them save time and avoid abuses? One of the most frequently recurring pieces of advice to the local magistrates in the "Shih-cheng lu» is that they should not accept plaints lightly. Refusing obviously ungrounded plaints was the best way to avoid some of the most frequent abuses, and to save time and money. This way, if the number of cases could be reduced by refusing to accept unreliable accusations, officials would have enough time to deal with important procedures themselves, so that runners and clerks would not be given the opportunity to abuse their authority. However, it seems to us that even if officials refused to accept all «unreasonable» accusations, dealing with all important judicial procedures personally would probably consume as much time as they wasted on dealing with false and ungrounded charges.

69 A second basic guideline that features prominently in Lü K'un's manual is that local officials should not confine themselves to the letter of the law. They should also use their own common sense and experience in investigating and judging, for instance when judging cases of «illicit sex» among the lower classes of the population. This «consideration» he expects from local officials consumes more time and energy than a simple, «blind» application of the law would do.

70 As these examples show, there are often conflicts between Lü K'un's ideals and principles, especially between the ideal of ensuring a humane treatment of suspects 
and convicts, and the ideal of efficiency and saving time (which would allow the official to handle more matters personally, and to prevent abuses). These ideals are often difficult to unite for Lü K'un, who is constantly trying to find a compromise and a reasonable balance between them.

One of the most striking manifestations of this conflict between principles can be found in Lü K'un's advice on illegal torture: inspired by his ideal of humaneness, he does not approve of it, and he even wants to convince officials to avoid, as much as possible, any form of torture, whereas, pushed by his ideal of efficiency and saving time, he acknowledges that some forms of - legal and illegal - torture can be used, under certain restrictions, when a suspect who is clearly guilty refuses to confess.

His whole handbook is full of attempts to find such compromises. Lü K'un had a sharp and accurate view on some of the most acute judicial problems in his time. His solutions were realistic, but they often consisted of compromises that were probably not always easy to maintain in reality. The fact that his handbook remained important during the Ch'ing dynasty (1644-1911) proves, however, that officials who had real experience of the problems addressed by Lü K'un accepted his solutions as realistic.

\section{BIBLIOGRAPHY}

Bodde, D., Morris, C., Law in Imperial China, Cambridge, Harvard University Press, 1967.

Ch'en, P., Chinese Legal Tradition under the Mongols, Princeton, Princeton University Press, 1979.

Ch'ü, T., Local Government in China under the Ch'ing, Cambridge, Harvard University Press, 1962.

Elman, B., A Cultural History of Civil Examinations in Late Imperail China, Berkeley and Los Angeles, University of California Press, 2000.

Franke, W., An Introduction to the Sources of Ming History, Kuala Lumpur, University of Malaya Press, 1968.

Giles, H., The 'Hsi Yuan Lu' or instructions to coroners, Proceedings of the Royal Society of Medicine, 1924, 27, pp. 59-107.

Goodrich, L., Fang, C., (Eds), Dictionary of Ming Biography 1368-1644, New York and London, Columbia University Press, 1976.

Handlin, J., Action in Late Ming Thought: The Reorientation of Lü K'un and Other Scholar-Officials, Berkeley, University of California Press, 1983.

Heijdra, M., The socio-economic development of rural China during the Ming, in Twitchett, D., Mote, W., (Eds), The Cambridge History of China, vol. VIII, The Ming Dynasty 1368-1644, part 2, Cambridge, Cambridge University Press, 1998, pp. 417-578.

Hsia, C., (Ed.), Tz’u-hai («Sea of words»), Shang-hai, Tz’u-shu Ch’u-pan-she (Dictionary Press), 1989. 
Huai, H., Hsing-fa («Penal law»), in Chang, C. (Ed.), Chung-kuo fa-chih t'ung-shih («A comprehensive history of the Chinese legal system»), vol. 7, Pei-ching, Fa-lü Ch'u-pan-she (Law Press), 1998, pp. 411-499.

Huang, P., Civil Justice in China, Stanford, Stanford University Press, 1996.

Huang, R., 1587: Le déclin de la dynastie des Ming, Paris, Presses Universitaires de France, 1985.

Hucker, C., The Traditional Chinese State in Ming Times (1368-1644), Tucson, The University of Arizona Press, 1961.

Hucker, C., The Censorial System of Ming China, Stanford, Stanford University Press, 1966.

Hucker, C., A Dictionary of Official Titles in Imperial China, Stanford, Stanford University Press, 1985.

Hucker, C., Ming Government, in Twitchett, D., Mote, W., (Eds), The Cambridge History of China, vol. VIII, The Ming Dynasty 1368-1644, part 2, Cambridge, Cambridge University Press, 1998, pp. 9-105.

Hummel, A., (Ed.), Eminent Chinese of the Ch'ing Period, Washington, United States Government Printing Office, 1943.

Jiang, Y., Defending the dynastic order in a local society, Ming Studies, 2000, 4, pp. 16-39.

Langlois, J., The code and ad hoc legislation in Ming law, Asia Major, 1993, VI, 2, pp. 85-112.

Langlois, J., Ming Law, in Twitchett, D., Mote, W., (Eds), The Cambridge History of China, vol. VIII, The Ming dynasty 1368-1644, part 2, Cambridge, Cambridge University Press, 1998, pp. 172-220.

Lü K'un, Shih-cheng lu, in Pei-ching T'u-shu-kuan Ku-chi Ch'u-pan Pien-chi-tsu (Editorial Board for the Publication of Ancient Books from the Pei-ching Library), (Ed.), Pei-ching t'u-shu-kuan kuchi chen-pen ts'ung-k'an («Collection of rare ancient books from the Pei-ching Library»), vol. 48, Pei-ching, Shu-mu Wen-hsien Ch'u-pan-she, 1992, pp. 1-308.

Mc Knight, B., Village and Bureaucracy in Southern Sung China, Chicago and London, The University of Chicago Press, 1971.

Mc Knight, B., The Washing away of Wrongs: Forensic Medicine in Thirteenth-Century China, Michigan, Center for Chinese Studies, 1981.

Münzel, F., Strafrecht im alten China nach den Strafrechtskapiteln in den Ming-Annalen, Wiesbaden, Otto Harrassowitz, 1968.

Parsons, J., Bureaucracy: aspects of background forces, in Hucker, C., (Ed.), Chinese Government in Ming Times, New York and London, Columbia University Press, 1969, pp. 175-212.

Pollard, D., Life in prison, Renditions, 1990, 33-34, pp. 195-200.

Sommer, M., Sex, Law, and Society in Late Imperial China, Stanford, Stanford University Press, 2000.

Tsang, L., (Ed.), Chung-kuo jen-ming ta tz'u-tien («A Chinese biographical dictionary»), T’ai-pei, Shang-wu Yin-shu-kuan (Commercial Press), 1921.

Tsang, L., (Ed.), Chung-kuo ku-chin ti-ming ta tz'u-tien («A dictionary of Chinese geography past and present»), T'ai-pei, Shang-wu Yin-shu-kuan (Commercial Press), 1931.

T’ung, K., Min-shi Fa-lü («Civil law»), in Chang, C., (Ed.), Chung-kuo fa-chih t’ung-shih («A comprehensive history of the Chinese legal system»), vol. 7, Pei-ching, Fa-lü Ch'u-pan-she (Law Press), 1998, pp. 161-308.

Van Gulik, R., T'ang-yin-pi-shih, Parallel Cases from Under the Pear-Tree, Leiden, E.J. Brill, 1956. 
Yang, L., Ming local administration, in Hucker, C., (Ed.), Chinese Government in Ming Times, New York and London, Columbia University Press, 1969, pp. 1-21.

\section{NOTES}

2. A general introduction to the governmental system during the Ming dynasty (1368-1644) can be found in Hucker (1961). This work provides a clear analysis of the structure of the imperial government during the Ming. It contains primarily information on the central government agencies. A more detailed study of Ming government, and especially of government personnel during the Ming, at both central and local levels, can be found in Hucker (1998; 1966). The latter is a collection of studies by different scholars on detailed aspects of Ming government, such as the statistical material on Ming local administration presented by L. Yang. Hucker (1966) analyses in detail the organizational structure of the censorial system, the system of surveillance over all governmental organs and actions, during the Ming. Two works that deal with the situation of local government agencies are Mc Knight (1971) and Ch'ü (1962). Both raise interesting points on the appointment, promotion and demotion of officials, on the selection and recruitment of personnel by local officials, and on the disciplinary control over their staff. Mc Knight (1971) analyses the local situation during the Southern Sung (1127-1279), whereas Ch'ü (1962) gives detailed information on the functions of, and the relations between, all the different groups of local government personnel (officials, their clerks, personal servants, private secretaries, etc.) during the Ch'ing dynasty (1644-1911). A basic introduction to penal law during the Ming can be found in Münzel (1968). This work offers a translation of one of the monographs on Ming law included in the «Ming-shih», the official dynastic history of the Ming.

3. On the use of magistrate handbooks, especially in the context of civil law, see Huang (1996). In the chapter 8 of his work («From the perspective of magistrate handbooks»), he analyses the advice of compilers of handbooks during the Ch'ing (1644-1911) on both formal adjudication and informal mediation in civil matters. Langlois (1998) contains a short analysis (pp. 205-206) of one Ming handbook, the «Fa-chia tsung lun» («General teachings for the jurist»), and an appendix by T. Nimick, who lists more than 20 titles of Ming handbooks for local magistrates, with short notes on their authors and contents.

4. Translated by Van Gulik (1956).

5. Bodde, Morris (1967, p.145).

6. Translated by Giles (1924) and Mc Knight (1981).

7. Mc Knight (1981, p. 31).

8. See Ch'en (1979, p. 91).

9. Langlois (1998, p. 207).

10. Part II (pp. 103-213) of Handlin (1983) is entirely dedicated to Lü K'un. In this section, Handlin analyses a number of Lü K'un's works, such as his writings for women and children, his work on city defence, and his medical works.

11. The system of recruitment through examinations was the most important system for recruiting civil officials during the Ming. The first phase of these examinations, which were conducted every three years, were the provincial examinations, in each provincial capital, in Peiching, and in Nan-ching. Those who passed these provincial examinations could sit the metropolitan examination in the capital. This was followed by a palace examination, where those who had passed the metropolitan examination were divided by rank into three groups. Metropolitan graduates could begin a career in the civil administration. See Hucker (1985, p. 81). 12. That Lü K'un is traditionally regarded as a person of exceptional integrity also appears from the notes on his life in the «Chung-kuo jen-ming ta tz'u-tien» («A Chinese biographical dictionary»): «He paid attention to moral education; his actions were just and wise». See Tsang (1921, p. 338). 
13. The ministry of personnel (li-pu) was responsible for appointments, demotions, promotions and evaluations of officials and sub-official functionaries. It was subdivided into four bureaus: the 'bureau of appointments', the 'bureau of honours', the 'bureau of merit titles', and the 'bureau of evaluations'. See Hucker (1985, p. 306).

14. Administration vice-commissioners (ts'an-cheng) worked in the provincial administration commissions, agencies at the provincial level that conducted the general administrational matters of local units of territorial administration (prefectures, sub-prefectures and districts). Normally the vice-commissioners were detached from the headquarters of the commission to serve in a branch office with a specific function or in a specific region. See Hucker (1985, p. 517).

15. Surveillance commissioners (an-ch'a shih), of which one was appointed in each province, were charged with overseeing judicial matters and with surveillance activities. See Hucker (1985, p. 103).

16. The administration commissioners ( $p$-cheng shih), of which two were appointed in each province, were the heads of the above-mentioned provincial administration commission. See Hucker (1985, p.127).

17. Parsons (1969, pp. 181-184) has tried to calculate the relative political power of the Chinese provinces during the Ming, based on the number of official posts in each individual province out of the total number of official positions, and on the ratio between official positions and total population in each province. The author concludes that the provinces of Shan-tung, Shan-hsi and Shen-hsi, where Lü K'un held important provincial positions, were moderately powerful provinces.

18. Franke (1968, p. 183).

19. Lit. "guardians of the customs and laws», an unofficial reference to members of the censorate, a central government agency responsible for maintaining disciplinary surveillance over the officials and for checking judicial records, and of agencies such as the provincial surveillance commissions. Used as a general reference to officials responsible for inspecting and supervising the (local) magistrates. Hucker (1985, p. 213).

20. For a biography of Lü K'un, see Goodrich, Fang (1976, pp. 1006-1008).

21. Huang (1996, pp. 198-202).

22. The first codified laws of the Ming («Lü-ling», «Codified laws and commands») were promulgated in 1368; in 1374, a drastically revised version of the code was promulgated; further revisions were made in 1376 and 1383, and finally in 1389. This final version was entitled «Ta Ming lü» («Great Ming code»). See Langlois (1998, pp. 172-173).

23. See Langlois (1993, pp. 87-90). The founder of the Ming, Chu Yüan-chang (emperor T'ai-tsu, 1368-1399), ordered that the code should remain unchanged. Flexibility, so as to keep in touch with changes in society, was brought into the system by means of ad hoc sub-statutes added to the fixed statutes in the code.

24. On the problem of how to apply the Ming code in changing Ming society, see Jiang (2000). Jiang studies the casebook of a local official in the district of Hsün (in what is now Ho-nan Province), to find how he tried to enforce the dynastic law code in a local, drastically changing context.

25. For the moral and practical nature of handbooks, see Huang (1996, pp. 198-222).

26. Lü K’un ([1598]1992, p. 194).

27. Lü K’un ([1598]1992, p. 189).

28. These 'sub-official functionaries' did not belong to the formally recognized group of magistrates. They belonged to the staff of officials on the prefectural, sub-prefectural and district levels. They were chosen from among the population by the office heads themselves, to become clerks or runners. The runners served the local magistrate as guards, policemen, lictors or messengers. See Hucker (1985, p. 392). 
29. During the Ming, official salaries were rather low in comparison to other dynasties. Nominally, they might have been the same, but they were only partially paid in rice, the remainder was paid in the form of paper money, silk, cotton, or silver, at low conversion rates. See Hucker (1985, p.82, and 1998, pp. 51-52).

30. For the various forms of corruption committed by local runners, see also Ch'ü (1962, pp. 67-70).

31. Lü K’un ([1598]1992, p. 188).

32. Lü K’un ([1598]1992, p. 187).

33. Ibid.

34. T'ai-yüan was a prefecture (now the T'ai-yüan District) in the present-day province of Shanhsi. See Tsang(1931, p. 143).

35. Lü K’un ([1598]1992, p. 193).

36. It is not very clear who this «sir Lü» in the text is; most probably, he was an investigating censor. Investigating censors normally worked in the central government agencies to check the records, but they could also be dispatched to inspect local units of territorial administration. See Hucker (1985, pp.145-146).

37. Ts'ang-nan is a coastal district in the present-day province of Che-chiang, near the border with Fu-chien. See Hsia (1989, p. 637).

38. Hai-yu was, originally, the name that referred to the region close to the Yellow Sea and the East China Sea; in the Ming, it became the name of a so-called 'circuit' (tao). These 'circuits' were subsections, one per province, among which investigating censors were distributed within the censorate (the central government agency in charge of disciplinary surveillance over the government officials, and of checking judicial records). The 'circuit' of Hai-yu corresponded to the province of Shan-tung. See Hsia (1989, p. 1058), and Hucker (1985, pp. 487-488).

39. Lü K’un ([1598]1992, pp. 192-193).

40. There were two kinds of «offences committed by officials»: «official offences» and "private offences». The "official offences» were committed in the official capacity of the magistrate, but not out of personal motives and without premeditation. «Private offences» were committed in the official or private capacity, out of personal motives. Both were punishable, the latter more severely than the former. Officials were however privileged to have punishments (except for death penalties) commuted to fines, reduction or deprivation of official rank. Only if they committed such an offence for the third time did they lose the right to redeem their punishment. See Münzel (1968, pp. 58-60).

41. Lü K'un ([1598]1992, p. 194).

42. For the legislation and penal measures against sexual offenders during the Ming and Ch'ing Dynasties, see Sommer (2000, pp. 66-165; 325-327).

43. See Sommer (2000, p. 88).

44. Lü K’un ([1598]1992, p. 195).

45. Sommer (2000, pp. 91-93) refers in this context to an interesting Ch'ing case of 1739, in which a woman and her daughter, belonging to a gang of itinerant beggars, were raped and then punished for illicit sexual intercourse. The author concludes that «the judiciary's stereotyped dichotomies (coercion/consent, chaste/unchaste) seem inadequate to capture the reality of sex as survival strategy at the bottom of Ch'ing society».

46. Lü K’un ([1598]1992, p. 198).

47. Interesting sources on prison life during the Ming are the «Ch'u-k'un chi» («Notes on suffering in prison») and the «Hsü ch'u-k'un chi» («Further notes on suffering in prison») by Yang Chüeh (1493-1549), an official who was imprisoned twice for a total period of seven years. On his life and suffering in prison, he wrote these two essays after his release. See Goodrich, Fang (1976, pp. 1506-1508). Also Tso Kuang-tou (1575-1625), an official who was involved in conflicts with other high officials, was incarcerated upon imperial order. From prison, he wrote a number of notes to 
his sons, describing the daily suffering and torture he endured. He did not survive his imprisonment. See Goodrich, Fang (1976, pp. 1306-1307). A similar contribution was made by Fang Pao (1668-1749, alternative name Fang Wang-hsi) in the Ch'ing dynasty; Fang, a scholar and prose writer, was imprisoned together with his whole family during a literary inquisition regarding a work to which Fang was said to have contributed. About his incarceration, he wrote the «Yü-chung chi» («Notes from prison»), later edited in the «Fang Wang-hsi ch'üanchi» («Collected works of Fang Wang-hsi»). See Hummel (1943, pp. 235-237). Fang Pao's «Yü-chung chi» have been translated by D.F. Pollard under the title «Life in Prison». See Pollard (1990).

48. See Ch'ü (1962, pp. 81-82).

49. Lü K’un ([1598]1992, p. 196).

50. Lit.: «those of whom the crime is serious, the evil is heinous, and of whom even death would not expiate all the crimes».

51. Lü K’un ([1598]1992, pp. 195-196).

52. On the financial situation of local government agencies and magistrates, see Ch'ü (1962, pp. 22-32).

53. The time limits could be extended, but in many cases this also involved a forfeiture of the magistrate's salary for a certain period of time. See Ch'ü (1962, p. 122).

54. Lü K’un ([1598]1992, p. 198).

55. Lü K’un ([1598]1992, p. 199).

56. Lü K’un ([1598]1992, p. 200).

57. The authors of some handbooks even saw a difference between the North and the South of China: the northerners were simple, whereas the southerners were crafty and entered more false accusations. See Huang (1996, p. 214).

58. This undoubtedly led to a conflict of interests: whereas the magistrates (because of time pressure and in order to secure a favourable evaluation) tried to keep the number of cases low, their clerks (in order to secure their income by collecting fees) frequently tried to convince and help people to enter accusations.

59. Bodde, Morris (1967, p. 189).

60. The penalty for entering a totally false accusation consisted of the punishment for the crime of which the plaintiff falsely accused somebody, increased by two or three degrees. For partially false accusations, the penalties were less severe: when wrongly accusing an accomplice of being the principal offender, the plaintiff was not punished; when accusing somebody of a more serious crime than the one he had actually committed, the plaintiff would get a punishment that was as severe as the difference between the punishment for the crime committed and the punishment for the crime that he falsely accused the defendant of. See Münzel (1968, p. 125).

61. Langlois (1998, p. 190).

62. Most authors of Ch'ing handbooks also favoured open sessions, since these sessions had large audiences, which meant that the comments of the magistrate would be published abroad as a warning to potential abusers. See Huang (1996, p. 212). During these sessions, the plaintiff and the accused could be confronted with each other. See Münzel (1968, p. 18).

63. Lü K’un ([1598]1992, pp. 197-198).

64. On the evaluations of officials by their superiors, see Ch'ü (1962, pp. 33-35) and Hucker (1985, p. 85).

65. According to the Ming code, the only authorized means of torture was flogging; this could be done only when evidence or testimony clearly proved that the accused was guilty, but he refused to confess. According to the code of the T'ang (618-907), a suspect could, during the hearings, be flogged only as many times as the code had provided as a punishment for the crime he was accused of (which varied between 10 and 50 strokes with the light bamboo, and between 60 and 100 strokes with the heavy bamboo), but this protective regulation no longer existed in Ming legislation. See Münzel (1968, p. 18). Besides flogging, the Ming code accepted only the wooden 
collarpiece (a large wooden block that was put on the shoulders of the convict, around his neck, so that he could not reach his head with his hands) as an additional punishment, but other forms of additional punishment or torture, such as fetters, handcuffs and finger presses, were commonly used and accepted in practice; even according to the pronouncements of the first Ming emperor, that were issued to supplement the permanent code, these «extra-legal punishments» were acceptable. See Huai (1998, pp. 459-466), and Langlois (1993, p. 88).

66. For these authorized instruments of punishment and torture, see also Münzel (1968, pp. 38-41).

67. Lü K’un ([1598]1992, p. 200).

68. Lü K'un ([1598]1992, p. 201).

69. Illegal torture included the use of extra-legal forms of torture, and applying torture to people who could not be tortured (such as torturing innocent people out of personal enmity).

70. These were the three basic units of territorial administration. By the end of the Ming, the empire was divided into 159 prefectures, 234 sub-prefectures, and 1,144 districts. See Hucker (1985, pp. 77-78).

71. Lü K’un ([1598]1992, p. 202).

72. Lü K'un ([1598]1992, p. 202, note under the article on «reporting murder cases»).

73. According to the Ming code, interest rates could not exceed three percent a month, and the total interest could not exceed the original amount. This legally fixed interest rate was only respected until the middle of the fifteenth century; from then on, the average interest rate was close to 100 percent a year, and, in particular cases, the yearly interest could even reach 600 percent. See T'ung (1998, pp. 248-249).

74. Lü K’un ([1598]1992, p. 205).

75. See Huang (1996, pp. 34-36).

76. Household divisions did not necessarily occur after the parents or grandparents were deceased; quite often, brothers divided up the family property during their parents' lifetime.

77. Lü K’un ([1598] 1992, p. 205).

78. See Huang (1996, pp. 26-27).

79. The Southern Sung (1127-1279, the period in which Sung Tz'u and Kuei Wan-jung lived) is thought to have had about 12,000 officials, of which 8,000 worked in the central government offices, and only 4,000 in local territorial units. See Mc Knight (1971, p. 8). In the beginning of the Ming, there were only 8,000 official posts; by the second half of the sixteenth century, their number had risen to 20,000 . See Huang $(1985$, p. 219). Heijdra (1998, p. 561) believes that there were between 25,000 and 40,000 officials during the Ming.

80. Such as the «Wu yüan lu», the «P'ing yüan lu» and the different works bearing the title «Hsi yüan chi-lu», all based on the original «Hsi yüan lu». See Mc Knight (1981, p. 31).

81. See Goodrich, Fang (1976, pp. 1007-1008).

82. Elman (2000, p. 719) gives the example of the prefecture of Ying-t'ien, where, among the policy questions asked on the civil examinations between 1474 and 1600 , only $15 \%$ were questions about law. 


\section{ABSTRACTS}

In addition to their judicial functions, local magistrates in imperial China had to perform many other tasks, without specializing in any one field. In order to ensure that these officials would have the necessary expertise, handbooks were compiled.

The «Shih-cheng lu» («Record of practical government»), a manual edited in 1589, contains sections that offer an extremely realistic insight into the functioning, difficulties and shortcomings of local judicial administration during the Ming dynasty (1368-1644). These sections - guidelines for surveillance officials - point out the many problems that surrounded local magistrates in Ming China: the constant threat of unfavorable evaluations, the continuous pressure of investigation deadlines, a large caseload, underpaid staff who did not hesitate to abuse their authority, and liability for punishment if they made wrong judgments. Lü K'un, the author of the manual, does not address these problems without advising magistrates on how to avoid them. By translating sections from the original classical Chinese text, and by situating them in the social and legal context of the Ming dynasty, we discover the motives and the sometimes conflicting - ideals of the author of this important work in the legal history of China.

Les magistrats locaux de la Chine impériale n'étaient pas spécialisés dans un domaine particulier et devaient accomplir de nombreuses tâches, à part de leurs fonctions judiciaires. Certaines sections du «Shih-cheng lu» («L'archive de la pratique du gouvernement»), un manuel édité en 1589 , nous fournissent un aperçu extrêmement réaliste du fonctionnement, des difficultés et des lacunes de l'administration judiciaire locale sous la dynastie Ming (1368-1644). Ces sections - des directives pour les fonctionnaires chargés de la surveillance - signalent les nombreux problèmes qui guettaient les magistrats locaux de la Chine des Ming: la menace constante d'évaluations négatives; la pression permanente pour respecter les délais imposés pour les enquêtes; la charge de travail importante; le personnel mal rétribué qui n'hésitait pas à abuser de son autorité; et enfin leur responsabilité personnelle en cas de jugement erroné. Lü K'un, l'auteur de ce manuel, aborde (néanmoins) ces difficultés en indiquant comment les prévenir. En traduisant certains passages de ce texte chinois classique et les situant dans le contexte social et légal de la dynastie Ming, nous découvrons les mobiles et les idéaux - parfois contradictoires - de l'auteur de cette importante œuvre de l'histoire juridique chinoise.

\section{AUTHOR}

\section{DOMINIEK DELPORTE}

University of Ghent, Chinese Language and Culture Department, Blandijnberg 2, 9000 Ghent -

Belgium, dominiek.delporte@rug.ac.be

Dominiek Delporte studied at the Chinese Language and Culture Department of the University of Ghent, Belgium, where he graduated in 1998. From 1998 to 2000, he studied at the Law Department of Fudan University, Shanghai. He is currently preparing his Ph.D. on judicial review procedures during the Chinese Ming dynasty (1368-1644) at the University of Ghent, where he holds a position as a research assistant. Co-author of: Heirman, A., Dessein, B., and Delporte, D., China: een maatschappelijke en filosofische geschiedenis ("China: asocial and philosophical history»), Ghent, Academia Press, 2001. 